\title{
原発性女子尿道癌の治療成績
}

\author{
癌研附属病院泌尿器科芷田合河尚

\section{RESULT OF THERAPY FOR PRIMARY CARCINOMA OF THE} \\ FEMALE URETHRA
}

\author{
Takashi Takeda and Tsuneo Kawai \\ Department of Urology, Cancer Institute Hospital
}

A study has been made of 10 women with primary carcinoma of the urethra treated from 1946 through 1975 at the Cancer Institute Hospital, Tokyo. The ages at the time of diagnosis ranged from 48 to 68 years. Protruding meatal masses were described by 3 patients (30 percent) and burning on urination by 2 . There were seen 5 cases of squamous cell carcinoma, 2 cases of transitional cell carcinoma, 2 cases of adenocarcinoma and 1 case of basal cell carcinoma. The lesions were staged retrospectively according to the TNM classification (classification 1968, trial period 1969-1973) and also criteria outlined by Grabstald and associates. Four cases were staged in T1, 2 cases in T2, 3 in T3 and 1 in T4. Prognosis was related to the clinical stage of the disease and patients in T1 and $\mathrm{T} 2$ were mostly favorable.

Six patients were treated with radiation therapy alone, 3 with a combination of radiotherapy and surgery and 1 by operation alone. Of the 9 patients treated with radiotherapy 2 received interstitial irradiation, $3 \mathrm{had}$ a combination of interstitial and external irradiation and 4 received external irradiation.

Two patients recently treated with a combination of radiation and surgery had received each dose irradiation followed by intramuscular injection of bleomycin. The frimary lesions in 9 of 10 cases were well controlled.

The complication that developed only in 2 patients treated with radiotherapy was urethral stricture which required periodical urethral dilatation.

Our current policy of the treatment will be summarized as follows. For the management of T1 either local excision or radiation therapy by interstitial irradiation using radium 226 and/or external irradiation is chosen, in case of T2 partial urethrectomy combined with irradiation is performed and in case of T3 or T4 radical surgery is combined with irradiation.

If metastases to lymph nodes are identified, pelvic lymph node and/or inguinal lymph node dissection is necessary.

要旨：1946年から1975年をでの30年間に癌研で治療を行なつた原発性女子尿道癌10例の治療成績を検討した. 年齡は48歳から68歳である. 主訴は外尿道口の腫瘤 3 例, 排尿痛 2 例などであつた. 組織型は扁平上皮癌が最 も多く 5 例，移行上皮癌 2 例，腺癌 2 例，基底細胞癌 1 例であつた. stage は TNM 分類 (1968年, 試行期間 1969年～1973年）と Grabstald ら（1966）の分類を用いた. T1 : 4 例, T2 : 2 例, T3: 3 例, T4: 1 例で, $\mathrm{T} 1, \mathrm{~T} 2$ 飞生存例が多い.

原発巣の治療は放射線療法単独 6 例，手術，放射線併用 3 例，手術単独 1 例であつた. 放射線療法を受けた 9 例中 2 例は組織内照射, 3 例は組織内照射と外部照射の併用, 4 例は外部照射であつた. 最近の 2 例に術後 照射に bleomycin を併用した. 一次治癒は10例中 9 例に得られた. 合併症として照射後尿道狭窄を 2 例経験 したが,これらに対して定期的拡張を行なつた。

われわれは報告例扣よび文献的考察により次の様な stage 別治療方針を想定した. T1：切除又は放射線単 
独療法，T2：尿道部分切除と放射線療法の併用，T3，T4:根治的手術療法扰よび放射線療法の併用. 所属リン パ節に対する治療は転移を認めれば根治的腸骨単径部リンパ節廓清術めるいは骨盤リンパ節廓清術を行なう。

\section{はじめに}

原発性女子尿道癌は稀な疾患であり,さらに組織型 も扁平上皮癌，移行上皮癌，腺癌等種々あるが，まだ stage 別，組織型別の治療方針が確立されて括らず，そ の予後は悪い. 近年, その治療法は放射線療法から手術 と放射線との併用療法へと変つて来つつある. 癌研附属 病院で治療した10症例の成績について調查し，治療方法 につき若干検討したので文献的考察と共に，ここに報告 する.

\section{研究の対象と方法}

1946年 1 月より 1975年末までの 30 年間に癌研附属病院
放射線科ならびに泌尿器科で治療した原発性女子尿道癌 10例を調査対象とした。

stage は病歷記載をもとに UICC の TNM 分類 (classified 1968，trial period 1969 1973) と浸潤度分 類 ${ }^{8}$ (表 1 ) 亿統一しな拉した. $\mathrm{T}$ 分類は腫瘍存在部位, 大きさ, 周囲組織への進展状況，可動性， $\mathrm{N}$ 分類は単径 リンパ節の触診所見，M分類は胸部 $\mathrm{X}$ 線像，全身触診所 見をるとに判定した.リンパ系造影は行なつていない. 治療法は放射線療法, 手術あるいはとの併用療法が行 なわれている，放射線療法は radium 針あるいは radon seed の組織内照射， ${ }^{60} \mathrm{Co} \gamma$ 線，Linac X線，Linac 電

表 1 Stage

a. TNM (classified 1968, Trial Period 1968-1973)

$\mathrm{T}$ (primary tumor)

TIS Pre-invasive carcinoma.

T 1 Tumor limited to the lower half of the urethra and movable.

T 2 Tumor originating in the lower half of the urethra, not involving the upper half but extending to the vulva and movable.

T 3 Tumor originating in, or extending to, the upper half of the urethra and/or extending into the bladder but remaining movable.

T 4 Tumor extending to surrounding structure, other than the vulva or bladder, and fixed.

$\mathrm{N}$ (regional lymph node)

The clinician may record whether palpable nodes are considered to contain growth or not

N 0 No palpable nodes.

N 2 Movable unilateral nodes.

$\mathrm{N}$ la Nodes not considered to contain growth.

$\mathrm{N} 1 \mathrm{~b}$ Nodes considered to contain growth.

N 1 Movable bilateral nodes.

$\mathrm{N} 2$ a Nodes not considered to contain growth.

$\mathrm{N} 2 \mathrm{~b}$ Nodes considered to contain growth.

N 3 Fixed nodes.

$M$ (distant metastases)

M 0 No evidence of distant metastases.

M 1 Distant metastases present.

b. Staging (Grabstald et al. 1966 ${ }^{8}$ )

Stage 0. - In situ (limited to mucosa).

Stage A. - Submucosal (not beyond submucosa).

Stage B. - Muscular (infiltrating periurethral muscle).

Stage C. - Periurethral.

1. Infiltrating muscular wall ot vagina.

2. Infiltrating muscular wall of vagina with invasion of vaginal mucosa.

3. Infiltrating other adjacent structures such as bladder, labia, clitoris.

Stage D. - Metastases.

1. Inguinal lymph nodes.

2. Pelvic lymph nodes below aortic bifurcation.

3. Lymph nodes above aortic bifurcation.

4. Distant. 
子線による外部照射と多岐にわたつている。これは長期 間にわたる少数例の集積であるから放射線源の進歩と共 に変遷していることで，確固たる治療方針があつたわけ ではない。したがつて治療法別の比較検討は出来ない. 予後算定の起点は初回治療終了日とし，1978年12月31日 現在の成績である. 生存率については少数例のため算出 されていない，最後に，これら症例の分析と文献的考察 から stage 別の治療方針の確立を試みた.

\section{結 果}

\section{1. 症例の概括}

年龄分布は表 2 亿示す如く，48歳から68歳までで平均 56歳であつた。組織学的には扁平上皮癌 5 例 (T1 : 4 例, $\mathrm{T} 2: 1$ 例), 移行上皮癌 2 例 (T2: 1 例, $\mathrm{T} 4:$ 1 例), 腺癌 2 例 ( $\mathrm{T} 3$ ), 基底細胞癌 1 例 ( $\mathrm{T} 3$ ) であつ た. 主訴（表 3 ） は外尿道口の腫瘤 3 例，排尿時疼痛 2 例, 尿閉, 出血, 排尿困難, 肉眼的血尿, 排尿後の異和 感が各 1 例であつた。

治療法は表 4 亿示す如く放射線療法が主体であるが， その方法は種々である. 組織内照射*が 2 例, 組織内照 射と外部照射の併用**が 3 例，外部照射***が 4 例であ つた. 一方, 放射線療法単独 6 例, 手術単独 1 例, 放射 線・手術併用療法 1 例, 放射線 - 手術 - bleomycin の 3 者併用が 2 例である. 放射線療法単独 6 例中 5 例に腫瘍 は消失した. その後の再発については不明 1 例（症例 4) を除く 4 例には原発巣再発は見られなかつた．放射 線療法無効例は症例 5 の 1 例のみであつた。 これは T2
表 2 Primary Carcinoma of Urethra in Women C.I.H. 1946-1975

\begin{tabular}{c|c|c|c|c|c|c|l}
\hline $\begin{array}{c}\text { Case } \\
\text { No. }\end{array}$ & Year & Age & $\mathrm{T}$ & $\mathrm{N}$ & $\mathrm{M}$ & Stage & \multicolumn{1}{|c}{ Histology } \\
\hline 1 & 1954 & 56 & 3 & $2 \mathrm{a}$ & 0 & $\mathrm{C}$ & Basal cell carcinoma \\
\hline 2 & 1954 & 48 & 1 & 0 & 0 & $\mathrm{~B}$ & Squamous cell ca. \\
\hline 3 & 1956 & 49 & 3 & 0 & 0 & $\mathrm{C}$ & Adenocarcinoma \\
\hline 4 & 1956 & 53 & 3 & $\mathrm{x}$ & 0 & $\mathrm{C}$ & Adenocarcinoma \\
\hline 5 & 1958 & 56 & 2 & $1 \mathrm{~b}$ & 0 & $\mathrm{D}-1$ & Squamous cell ca. \\
\hline 6 & 1964 & 55 & 4 & $2 \mathrm{~b}$ & 1 & $\mathrm{D}-4$ & Transitional cell ca. \\
\hline 7 & 1966 & 51 & 2 & 0 & 0 & $\mathrm{~B}$ & Transitional cell ca. \\
\hline 8 & 1973 & 56 & 1 & 0 & 0 & $\mathrm{~A}$ & Squamous cell ca. \\
\hline 9 & 1974 & 67 & 1 & 0 & 0 & $\mathrm{~B}$ & Squamous cell ca. \\
\hline 10 & 1975 & 68 & 1 & 0 & 0 & $\mathrm{~B}$ & Squamous cell ca. \\
\hline
\end{tabular}

表 3 Chief Complaint

\begin{tabular}{l|l}
\hline \multicolumn{1}{c|}{ Chiet complaint } & \multicolumn{1}{c}{ No. of Cases } \\
\hline Tumor mass & 3 (case $2,8 \& 10)$ \\
\hline Burning on urination & 2 (case $5 \& 7$ ) \\
\hline Urinary retention & 1 (case 1$)$ \\
\hline Bleeding & 1 (case 4$)$ \\
\hline Dysuria & 1 (case 3$)$ \\
\hline Macroscopic hematuria & 1 (case 6$)$ \\
\hline Discomfort after urination & 1 (case 9$)$ \\
\hline
\end{tabular}

表 4 Treatment of Primary Lesion and Prognosis (Dec. 31, 1978)

\begin{tabular}{r|l|c|c|c}
\hline $\begin{array}{r}\text { Case } \\
\text { No. }\end{array}$ & \multicolumn{1}{|c|}{ Treatment (Modality) } & Local Result & Recurrence & Outcome \\
\hline 1 & Radium needles* & controlled & - & dead \\
\hline 2 & Excision, ${ }^{60}$ Co $r$-ray $* * *$ & controlled & + & alive \\
\hline 3 & Radium needles, ${ }^{60}$ Co $r$-ray $* *$ & controlled & - & dead \\
\hline 4 & Radium needles, ${ }^{60}$ Co $r$-ray $* *$ & controlled & unknown & dead \\
\hline 5 & $\begin{array}{l}\text { Radium needles, Radon Seeds, } \\
60 \text { Co } r \text {-ray }{ }^{* *}\end{array}$ & failed & $\ldots$ & dead \\
\hline 6 & Linac X-ray ${ }^{* * *}$ & controlled & - & dead \\
\hline 7 & Radium needles $*$ & controlled & - & alive \\
\hline 8 & Excision & controlled & - & alive \\
\hline 9 & $\begin{array}{l}\text { Excision, Linac electron } \\
\text { combined with BLM } * * *\end{array}$ & controlled & - & alive \\
\hline 10 & $\begin{array}{l}\text { Excision, Linac electron, } \\
\text { Linac X-ray combined with BLM } * * *\end{array}$ & controlled & - & alive \\
\hline
\end{tabular}

* : interstitial irradiation. BLM : bleomycin

** : interstitial irradiation + external irradiation.

*** : external irradiation. 
表 5 Alive Cases (Dec. 31, 1978)

\begin{tabular}{r|c|c|c|c}
\hline $\begin{array}{c}\text { Case } \\
\text { No. }\end{array}$ & Stage & Recurrence & $\begin{array}{c}\text { Treatment for } \\
\text { Recurrence }\end{array}$ & Post Treatment Period \\
\hline 2 & T 1 & $\begin{array}{c}\text { 3 yrs after } \\
\text { primary treatment }\end{array}$ & $\begin{array}{c}\text { Excison, } \\
60 \text { Co } r \text {-ray }\end{array}$ & $23 \mathrm{yrs}$. \\
\hline 7 & T 2 & - & $\cdots$ & 12 yrs. 9 mos. \\
\hline 8 & T 1 & - & $\cdots$ & 5 yrs. 6 mos. \\
\hline 9 & T 1 & - & $\cdots$ & 3 yrs. 9 mos. \\
\hline 10 & T 1 & - & $\cdots$ & 3 yrs. 2 mos. \\
\hline
\end{tabular}

の扁平上皮癌で radium 針の組織内照射, radon seed の 追加刺入の繰り返し， ${ }^{60} \mathrm{Co}$ 照射など種々な放射線療 法を 5 カ月半にわたり行なつたが，無効であつた。 経過 不明例（症例 4）は放射線療法後約 2 力月間は腫瘍の縮 小を見たが，その後の追跡調査が出来ず，再発の有無， 死因などは不明である.

手術の 4 例については何れる腫瘍切除が行なわれた. その内 3 例に術後照射が行なわれた．その内 1 例（症例 2) が 3 年後再発した. それに対し，再度摘出， ${ }^{60} \mathrm{Co}$ 照射を行ない，腫瘍は全く消失し20年後の現在健在であ る. 最近の扁平上皮癌の 2 例（症例 $9 ， 10 ） に は$ 腫瘍切 除後, 放射線と bleomycin の併用を行なつた. 症例 9 は総線量 3,200rads/ 8 回/27日で照射後30分以内に bleomycin $10 \mathrm{mg}$ 筋注し, 総量は60mg であつた. 症例10は 総線量6,000 rads/30回/49日で照射30分以内に bleomycin $5 \mathrm{mg}$ を13回，2.5mg を15回筋注し，総量 $102.5 \mathrm{mg}$ であ つた.

生存例（表 5 ）は 5 例である. 症例 2 の再発治癒以外 の 4 例は再発転移なく生存している. 死亡例（表 6) は 10例中 5 例であつた. 癌死は 2 例（症例 $5 ， 6$ ）で， 1 例は治療後16力月で原発栄悪化による死亡，他の 1 例は 9 カ月で転移巣悪化による死亡であつた. 原因不明死 が 1 例 (症例 4), 他病死（症例 1 : 脳血管障害, 症例
3 : 白血病) が 2 例であつた。これら 3 例の原病の再発 は不明であつた，総じて生存例は $\mathrm{T} 1$ に多く, 死亡例は T3, T4 飞多い.

転移例は 2 例（症例 5，6．何れも死亡）で初診時有 転移例であつた，治療中あるいは治療後転移が発生した ものはない, 症例 5 は左単径部リンパ節転移, 症例 6 は 両側単径リンパ節，左鎖骨上窩リンパ節，左怪骨への転 移であつた。転移巣治療法は症例 5 で摘出, 症例 6 で放 射線療法であつた，症例 5 で転移巣の再発は無かつた が, 症例 6 では放射線療法が無効であつた.

後遺症として症例 7,10 亿照射後, 尿道狭窄が見られ た.これらに対しては定期的な尿道拡張を行なつてい る.

次に各症例の概要を記す.

2. 症例

症例 1. 56歳, T3, N2a M0, 主訴は尿閉. 両側単径 部に小指頭大の腫瘤 2 個触知したが，特に治療はしなか つた. 外尿道口には異常なく, 腔触診で腫瘤を触れた。 原発巣に対し radium 針組織内照射 (線量 : $1,665 \mathrm{mgh}$ ) を行なつた． 2 カ月後の局所生検で癌細胞を認めず，そ の後特に異常なく原発巣治療後10か月で脳血管障害を併 発して死亡した.

症例 2. 48歳, TI, N0, M0, 主訴は外尿道口の腫瘤.

表 6 Dead_Cases

\begin{tabular}{c|c|c|c|l|c}
\hline $\begin{array}{r}\text { Case } \\
\text { No. }\end{array}$ & Stage & Metastasis & $\begin{array}{l}\text { Treatment for } \\
\text { Metastasis }\end{array}$ & Cause of Death & Post Treatment Period \\
\hline 1 & T 3 & - & $\ldots$ & $\begin{array}{l}\text { cerebrovascular } \\
\text { disease }\end{array}$ & 10 mos. \\
\hline 3 & T 3 & - & $\ldots$ & leukenia & 4 yrs. \\
\hline 4 & T 3 & unknown & unknown & unknown & unknown \\
\hline 5 & T 2 & ing uinal & excision & primary cancer & 16 mos. \\
\hline 6 & T 4 & $\begin{array}{l}\text { inquinal } \\
\text { supra-clavicula } \\
\text { r-tibia }\end{array}$ & radiation & $\begin{array}{l}\text { metastasis of } \\
\text { the disease }\end{array}$ & 9 mos. \\
\hline
\end{tabular}


外尿道口に拇指頭大の腫瘤があり, 腫瘤切除叔よび外部 照射 $\left({ }^{60} \mathrm{Co} \gamma\right.$ 線)を行なつた. 3 年後, 再発したが, 再 び切除㧊よび外部照射 $\left({ }^{60} \mathrm{Co} \gamma\right.$ 線 : 5,750 rads)を行ない 治癒した．治療開始後 23 年目の現在健在である.

症例 3. 49歳, T3, N0, M0, 主訴は排尿困難. 胵触 診で胵前壁に腫瘍の浸潤があり，尿道全体にほぼ一致し て硬い小指頭大の腫瘤を触れた. 原発巣は radium 針 組織内照射 (線量 : $3,824 \mathrm{mgh}$ ), 外部照射 $\left({ }^{60} \mathrm{Co} \gamma\right.$ 線 : 1,000 rads) で治癒した. しかし, その後白血病を併発 し, 原発巣治療後 4 年で死亡した.

症例 4.53歳, T3, NX, M0, 主訴は外陰部からの出 血. 外尿道口に拇指頭大の腫瘤があり, 腔触診で尿道全 体に小指大の硬い腫瘤が触れた. 原発巣に対してradium 針組織内照射 (線量 : $5,203 \mathrm{mgh}$ ), 外部照射 $\left({ }^{60} \mathrm{Co} \gamma\right.$ 線 : 1,480rads) を行なつた。約 1 カ月間で尿道腫瘍は 非常に小さくなつた. 退院後一度も来院せず, 病歴記載 では死亡しているが，役所問い合せを行なつたが，死亡 年月日, 死因は不明である.

症例 5. 56歳, T2, N1b, M0, 主訴は排尿痛. 外 尿道口に超拇指頭大の腫瘤があり, 胵触診でも前部尿 道に腫瘤を触れ，小陰唇に浸潤を認めた. 左鼡径部に 晼豆大の腫瘤が触れた。原発巣に対して放射線療法を 行なつた. まず， radium 針を尿道周囲へ刺入 $(4,148$ $\mathrm{mgh)}$ ，さらに同部に radon seed 8 本刺した. 2 週間 後 radon seed 胵前壁にも6 本刺し, 外陰部に ${ }^{60} \mathrm{Co} \gamma$ 線 $(2,625 \mathrm{rads})$ 照射した。外部照射終了時に radon seed を胵前壁へ 2 本, 1 カ月半後に radon seed 2 本，4 カ月後に25本刺入した. しかし局所の治療効果は 得られなかつた。左巣径部リンパ節転移に対してはリ ンパ節摘出を行ない control 出来た。 しかし原発巣を control 出来ず, 治療開始後16カ月で癌死した.

症例 6. 55歳, T4, N2b, M1, 主訴は血尿. 外尿道 口が左側へ偏位し, 胵触診で超䳕卵大の腫瘤を胵前壁に 触れた. 膀肤二重造影で膀胱左底部が不規則な陰影欠損 像を示し, 膀羘への浸潤が考劣られた。原発巣に対して 外部照射 (Linac X線 : 5,200rads), 両側鼡径部に対し ても外部照射 $(4,540 \mathrm{rads})$ を行なつた. 局所放射線治療 後10日目の膀胱造影では腫瘍の存在が認められない程に 改善を示した. 後腹膜リンパ節転移は静脈性腎孟造影上 疑つたが，特に治療を行なわなかつた，右怪骨，左鎖骨 上窩リンパ節に転移あり外部照射（右怪骨 : $5,950 \mathrm{rads}$, 左鎖骨上䆚：3,200 rads）を繰り返したが効果なく，治療 開始後 9 カ月で遠隔転移のため死亡した.
症例 7. 51歳，T2，N0，M0，主訴は排尿初期痛. 腫 瘍は外尿道口を被い小陰唇まで達していた. 特に外尿道 口の左側に硬結が強く, 原発巣に対して radium 針組織 内照射 $(2,822 \mathrm{mgh})$ を行なつた. 照射後尿道狭窄を来 たしているが，12年目の現在健在である.

症例 8. 56 歳, $\mathrm{T} 1, \mathrm{~N} 0, \mathrm{M} 0$, 主訴は外尿道口の腫瘤. 外尿道口に小指頭大の腫瘍があり，大きな caruncula の 外観であつた. 切除だけで 5 年 6 カ月の現在健在であ る.

症例 9. 67歳, T1, N0, M0, 主訴は排尿後異和感. 外尿道口に $13 \times 10 \mathrm{~mm}$ の腫瘤があつた. 切除および電子 線外部照射 $(3,200 \mathrm{rads})$ と bleomycin $60 \mathrm{mg}$ との併用 療法を行なつた. 3 年 9 カ月の現在健在である.

症例10. 58 歳. $\mathrm{T} 1, \mathrm{~N} 0, \mathrm{M} 0$, 主訴は外尿道口の腫 瘤. 外尿道口に $29 \times 26 \mathrm{~mm}$ の腫瘤があり, そのために 外尿道口は右下方へ偏位していた. 切除および外部照 射（電子線： $2,600 \mathrm{rads}, \mathrm{X}$ 線 $: 3,400 \mathrm{rads}$ ) と bleomycin $102.5 \mathrm{mg}$ 併用療法を行なつた. その後, 尿道狭窄を来 たしたが 3 年 2 カ月の現在健在である.

\section{考 案}

原発性女子尿道癌の予後は一般に悪く表 7 に示す如 く，5年生存率は $14 \%$ 64\%と言われて招り, stage A ですら $50 \%$ 以下である3). これは稀な疾患なるが故 に stage 別の治療方針が確立されていないばかりでな く, 早期発見が難しく, かなり進行してから発見される ためでもある. 腫瘤触知を主訴とするるのは直ぐ診断 がつくが，これは $21 \%^{33} ， 38 \%^{8)}$ と意外飞少ない。膀胱 症状 $(25 \%)^{3)}$ や排尿障害を訴兄て来院するものでは発 見が遅れる. 最も多い症状 $(56 \%)^{3)}$ は尿道出血や下着 の出血斑であるが，この場合注尿道癌が一応疑兄る症 状であるから, 胵内診, 内視鏡検查の励行が大切であ る.

特に良性疾患として鑑別診断上問題となるものに caruncula がある. 普通 caruncula は尿道口の後壁に表 面平滑, 赤色の軟らかい直径 $1 \mathrm{~cm}$ 以下の腫瘤として存 在する. 臨床上, caruncula と見做していたものの内, $2.4 \%$ 悪性新生物であつたとの報告もあり ${ }^{11)}$, 組織学 上通常の移行上皮型と細胞異型性の少ない分裂を示す caruncula は癌と見誤ることがあり ${ }^{21)}$ ，癌と caruncula は混在する場合もある ${ }^{13) 21}$. 結局, すべての尿道腫場即 ち caruncula に対しても切除生検を必ず行なうべきであ $ろ^{5)}$.

1. 予後を左右する因子 
表 75 Years Survival Rate

\begin{tabular}{|c|c|c|c|c|c|}
\hline Year & Reference & $\begin{array}{c}5 \text { Years survival } \\
(\%)\end{array}$ & Radiation & Surgery & Both \\
\hline 1955 & Staubitz, W. J. et al. ${ }^{21)}$ & $9 / 27(33 \%)$ & $9 / 27$ & * & $*$ \\
\hline 1958 & $\begin{array}{l}\text { Brack, C. B. and } \\
\text { Dickson, R. J. }{ }^{21}\end{array}$ & $6 / 11(54 \%)$ & $3 / 8$ & $*$ & $3 / 3$ \\
\hline 1969 & Antoniades, J. ${ }^{11}$ & $14 / 22(63.6 \%)$ & $12 / 19$ & $0 / 1$ & $2 / 2$ \\
\hline 1969 & Rogers, R. E. ${ }^{19)}$ & $7 / 24(29 \%)$ & $*$ & $*$ & $*$ \\
\hline 1970 & $\begin{array}{l}\text { Zeigerman, J. } \mathrm{H}_{\dot{2} 5} \text { and } \\
\text { Gordon, S. F. }\end{array}$ & $27 / 181(14.9 \%)$ & $*$ & * & $*$ \\
\hline 1973 & Chu, A. M. ${ }^{41}$ & $7 / 22(31.8 \%)$ & $7 / 22$ & $*$ & * \\
\hline 1973 & Desai, S. et al. ${ }^{5)}$ & $5 / 16(31 \%)$ & $*$ & $*$ & * \\
\hline 1973 & Grabstald, H. ${ }^{9)}$ & $23 / 84(27 \%)$ & $4 / 29$ & $11 / 30$ & $8 / 24$ \\
\hline 1973 & Peterson, D. T. et al. ${ }^{14)}$ & $18 / 49(36.7 \%)$ & $6 / 20$ & $8 / 19$ & $4 / 10$ \\
\hline 1976 & Bracken, R. B. et al. ${ }^{3)}$ & $26 / 81(32 \%)$ & $19 / 53$ & $3 / 11$ & $2 / 9$ \\
\hline
\end{tabular}

予後を左右する因子で最る大切なるのは腫瘍の大き さ，発生部位，浸潤度，転移の有無などである．組織型 による差はむしろ無いとされている. Grabstald ら この予後を左右する因子の正確な診断のために，(1) 視 診 : 尿道, 陰唇, 腔, 単径部, 下肢. (2) 触診 : 腫瘍の 浸潤度，可動性をみるために麻酔下双手診を行ならこと と同時に骨盤リンパ節，䋃径リンパ節の状態も診る.

(3) 膀胱尿道鏡検査 : この巣際原発とその周辺の生検も 行なうこと. (4) 生検 : 腟, 陰唇, 単径リンパ節などを 行ならこと.などが大切な検索方法であるとしている。 Bracken $ら^{3)}$ は staging として足背式リンパ系造影検查 を推奖している.

1）腫瘍の大きさと予後

Bracken ら ${ }^{3)}$ (1976) は low stage の小さい腫瘍に対 し組織内照射を, high stage で大きな腫瘍には外部照射 を行ないその 5 年生存率は $2 \mathrm{~cm}$ 以下のもの $6 / 10,2 \sim 4$ $\mathrm{cm}$ のもの $13 / 27,5 \mathrm{~cm}$ 以上のもの $4 / 31$ と報告してい る.われわれの症例では $1 \sim 2 \mathrm{~cm}$ のもの 5 例中 3 例 生存 (12年 9 力月, 5 年 6 力月, 3 年 9 力月), $2 \sim 3 \mathrm{~cm}$ のもの 4 例中 2 例生存 (23年, 3 年 2 力月), $5 \mathrm{~cm}$ 以上 のもの 1 例は 9 カ月で死亡している.

\section{2）発生部位と予後}

女子尿道は後 3 分の 1 の proximal urethra が移行上 皮で被れ，前 3 分の 2 の distal urethra は扁平上皮から なつている. 臨床的には anterior (前 3 分の 1 尿道), posterior（後 3 分の 2 尿道）飞分㚈られ解剖学的位置と くいちがつている. しかし臨床的には戦密に区別するこ とは出来ず，外尿道口付近が anterior urethra でそれよ
り奥は posterior urethra と思つて差し支えない。

一般に anterior 型の成績は良く, posterior 型は悪 い. anterior 型は Antoniades $^{1)}$ (1969) が 5 年生存 $12 / 16$, Grabstald $^{9)}$ (1973) が14/29, Zeigerman ら ${ }^{25)}$ (1970) が 27/53などである.われわれのは 5/6（23年，12年 9 カ 月, 5 年 6 カ月, 3 年 9 カ月, 3 年 2 カ月) である. 死 亡例（症例 5) は16力月で癌死した. 一方, posterior 型 では 5 年生存率 $50 \%$ 以上の成績は見当らない，われわれ の 4 例（症例 $1 ， 3 ， 4 ， 6$ ） 6全例 5 年以内に死亡ᄂ ている. anterior 型の成績が良いのは早期発見が容易 で, 完全に切除出来るからである ${ }^{12)}$.

3）組織型と予後

5 年生存率は Peterson ら ${ }^{14)}$ (1973) が $1 / 1$ (腺癌, anterior 型),2/3 (移行上皮癌, anterior 型), 10/19 (扁 平上皮癌, anterior 型)，Zeigerman $5^{25)}$ (1970) は20 $\%$ (腺癌)，15\% (類表皮癌)， $12.5 \%$ (移行上皮癌), Grabstald $^{9}$ (1973) が11/20 (類表皮癌, anterior 型) 等 である. 組織型にもとづく生存率の差はないと一般的に は言われている゙๋.

2. 治療方法

1) 原発巣治療

1921年以前はもつぱら手術療法であつたが ${ }^{18)}$ ，その後 手術療法に代つてX線, radium needle が用いられる様 になつた ${ }^{10)}$. Ritter ${ }^{18)}$ (1953) は1933年から 1950年まで の諸家の治療法を文献的にまとめているが，この時期に は組織内照射法が大部分を占めている，それ以後は選択 的飞, 外尿道口限局性腫瘍飞組織内照射 ${ }^{15) 19) 21222)}$, 腫瘍 の直径が $4 \mathrm{~cm}$ 以上のものには他の放射線療法 ${ }^{21)}$ ，さら 
に進行したものでは組織内照射と外部照射の併用が行な われている15)19)21222．また部位別では vesico-urethral 型 飞根治手術療法 ${ }^{15)}$, entire 型飞放射線之手術の併用療 法914) が行なわれて来ている. 最近の報告では3), 粘膜 下までのものには組織内照射単独あるいはその後局所切 除する. 浸潤が筋層から隣接臓器即ち膀脱, 陰唇, 陰核 などまで括よんでいる場合，術前外部照射後，膀脱 尿道子宮胵全摘, 必要ならば vulvectomyを行なら. Roger $^{19)}$ (1969) は直径 $3 \mathrm{~cm}$ 以下の腫瘍に対して radium 針刺入が効果的で, $3 \mathrm{~cm}$ 以上のものには外部照射又は 骨盤蔵器摘出を勧めているが，大きさ，位置だけでなく 年齢，全身状態を考慮して治療法を決めなければならな いと言つている.

癌研の症例を遡及的にみると， T1 は腫瘍切除と外部 照射，T2，3 は組織内照射単独あるいは外部照射との併 用, $\mathrm{T} 4$ は外部照射であつた。 これは $\mathrm{T}$ 分類別の治療方 針があつたわけではなく，癌研の特殊性として1965年以 前は放射線科医の手で治療が行なわれていたので，放射 線療法が主体となつていたが, それ以後は泌尿器科医も 関与しているので手術と放射線との併用療法が多くなつ ている. 1965年以前に T3，4 が集中し，これらに対し て放射線療法が行なわれたが成績は良くなかつた。

最近の 2 例の原発巣（何れる T1）に対しては腫瘍切 除後放射線療法に bleomycin $(100 \sim 150 \mathrm{mg})$ を併用し た. 山下ら ${ }^{24)}$ (1974） は各種悪性腫瘍に対してこの併用 療法で相乗効果を期待し, bleomycin 100 200mg で少 なくとも1,000〜2,000 rads 放射線量は減少し得たと報 告し，われわれる併用療法を試みた。高部ら ${ }^{23)}$ (1976) の併用療法でX線又は bleomycin 感受性腫瘍では, 上 り大きな相乗効果も期待しうるので, 併用療法の有効性 は臨床での成果を待つべきであるとし，今後症例を重ね
て検討して行く必要がある.

われわれは以上の事柄を勘案して原発巣に対して次の 様な治療方針を想定した.

T1，2 の治療法は腫瘍が小さい (1.5cm 以下) 時に は, 腫瘍切除でも放射線療法でも単独で良い。大きい時 には腫瘍切除と放射線療法併用が良い。放射線療法とし て radium 針の刺入あるいは Linac 電子線による外尿 道口からの照射を行なう。

T3，4 の治療方針は根治手術と放射線療法の併用が好 ましい，根治手術とはとの症例毎に尿道全摘，尿道膀脱 全摘または膀腃尿道子宮胵全摘を選び，尿路変更術を行 ない必要ならば vulvectomyも行なう。

2）リンパ節転移治療

\section{(i) 紪径部}

尿道の前 3 分の 2 の所属リンパ節は単径部である. 鼡 径部転移の診断は大きさより，むしろその持続期間であ $\eta^{6)}$ ，又，リンパ節が直径 $1 \mathrm{~cm}$ 以上あるものは転移が濃 厚に疑光る ${ }^{7}$. 諸家の報告によると初診時単径部リンパ 節尰大は表 8 亿示す如く，14〜50\% で組織学的陽性は 4 〜 28\%と差がある.

営径部リンパ節に対しては触れる総べてのリンパ節の 生検を行ない，その結果に基づいて廓清術の決定がなさ れるべきである ${ }^{5}$. 女子尿道癌の場合, 単径りンパ節腫 脹は炎症よりる転移の可能性の方が大きい( ${ }^{9113}$ ので，炎 症であろらと考えてリンパ節切除を遅らすのは良くない 13). 䋃径部リンパ節転移の大部分は片側で病側を廓清す る. 対側はリンパ節が大さくなつた時に処理する ${ }^{15)}$.リ ンンパ節への外部照射は全く効果がないとの報告がある が ${ }^{21)}$ ，一方予防的に放射線療法を行ならことは価值があ るとの報告もあり ${ }^{16)}$ 定説はない，予防的単径部リンパ節 廓清の必要はないが ${ }^{5)}$, 単径部リンパ節転移に対しては

表 8 Inguinal Lymph node Metastasis

\begin{tabular}{c|l|c|c}
\hline Year & \multicolumn{1}{|c|}{ Reference } & $\begin{array}{c}\text { Enlarged inguinal } \\
\text { nodes at first visit }\end{array}$ & $\begin{array}{c}\text { Proved by biopsy } \\
\text { or dissection }\end{array}$ \\
\hline 1955 & Staubitz, W. J. et al. ${ }^{21)}$ & $15 / 32(47 \%)$ & $2 / 32(6 \%)$ \\
\hline 1958 & Monaco, A. P. et al. ${ }^{13)}$ & $5 / 23(22 \%)$ & $4 / 23(17 \%)$ \\
\hline 1966 & ${\text { Grabstald, H. et al. }{ }^{8)}}$ & & $22 / 79(28 \%)$ \\
\hline 1969 & Skjaeraasen, E. ${ }^{20)}$ & $13 / 25(52 \%)$ & $5 / 25(22 \%)$ \\
\hline 1973 & Chu, A. M. ${ }^{4)}$ & $3 / 22(14 \%)$ & \\
\hline 1973 & Peterson, D.T. et al. ${ }^{14)}$ & $10 / 49(20.4 \%)$ & $2 / 49(4 \%)$ \\
\hline 1973 & Desai, S. et al. ${ }^{5)}$ & $6 / 16(37.5 \%)$ & $2 / 16(12.5 \%)$ \\
\hline
\end{tabular}


根治的腸骨 - 単径部廓清術又は根治的膀胱部 - 仙骨部 腸骨部・単径部廓清術を行なら。も乙全身状態からみ て,これらの手術侵襲に耐えられなければ外部照射を行 なう。

(ii) 骨盤部

尿道の後 3 分の 1 の所属リンパ節は骨盤リンパ節であ り，転移好発部位は閉鎖リンパ節，子宮傍リンパ節，腸 骨リンパ節等である．Grabstald ら ${ }^{8)}$ (1966) は26例リン パ節検索を行ない，その内13例に骨盤内リンパ節の転移 を認めたが，真のリンパ節転移はこれょりも多いであろ うと報告している。 Bracken ら²（1976）は骨盤リンパ 節転移がある場合，廓清術の効果には疑問で放射線療法 を奖めている. しかし切除可能な転移巣が存在する場 合，全身状態が許せば郭清術の適応になると考える。

3）遠隔転移治療

遠隔転移の最も多い臓器は肺である。 その他に骨, 脳，肝，頭皮などがある. 遠隔転移症例は全例の 3

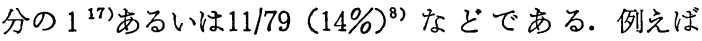
Monaco 5 ${ }^{13)}$ (1958) は33例中 1 例仠肝転移, Peterson $ら^{14)}$ (1973) は49例中 2 例飞脊椎, 肺, Desai $5^{5)}(1973)$ は16例中 1 例に肺，肝，われわれの症例は10例中 1 例に 右怪骨，左鎖骨上窩リンパ節に転移があつた，組織型で は Grabstald ら ${ }^{8)}$ (1966) は類表皮癌 5/59（8\%）より も腺癌 3/12 (25\%) の方が遠隔転移率大であると報告し ている. 治療に関して効果ある方法は文献的に見付から なかつた。限局したものであれば手術あるいは放射線療 法，多発していればその組織型に現在効果あると考兄ら れている化学療法剤を用いるのが適当と考学る. しかし その効果は今後の化学療法, 免疫療法の発展に期待すべ きであろう。

\section{3. 合併症}

原発巣に関して放射線によるものでは急性症状が皮膚 および粘膜の反応で深部紅斑から湿性剝離までで，晚期 症状は陰唇の浮腫, 皮膚および粘膜の萎縮と毛細血管拡 張，皮下の線維症等である ${ }^{21)}$. Monaco ら ${ }^{13)}$ (1958) は 放射線あるいは手術療法による合併症を 9 例報告し, 原 発巣治療によるるのは尿道狭窄 3 例, 放射線直腸肛門 炎 3 例，陰唇の放射線性壊死 1 例である. Taggart Б ${ }^{22)}$ （1972）は33例の放射線単独療法中，前部尿道の壊死 2 例，尿道胵瘦 1 例，放射線性回腸炎特よび右尿管狭窄 1 例, 直腸胵瘦 1 例である. われわれの症例では尿道狭窄 が 2 例発生し，金属 bougie で拡張を行ない良好な経過 である. 合併症は隣接臓器叔よび尿道そのものに発生し
ているが，合併症を少なくし尿道の機能をいかに保存す るか治療成績向上と共に今後の大きな課題である.リン 次節転移治療時の合併症として下肢浮腫，鼡径部皮膚壊 死リンパ液漏出などがある。 下肢浮腫に対してはマッ サージなどによる軽減を試みる．皮膚壊死は手術時の切 開線による栄養血管の問題，放射線照射によるものであ る. Monaco ら ${ }^{13)}$ (1958) は合併症を起こした 9 例中 4 例に groin sepsis を報告している.この皮膚壊死の対策 は手術（皮膚切開線，皮下脂肪切除などの工夫）と照射 法の工夫であるが，壊死が発生した場合は分層植皮ある いは有茎皮弁（血管などが露出している場合）による修 復を行なう。リンパ液漏出の対策は遊清時血管結禁と同 様にリンパ管も必ず結紮することで防げる.

\section{結 語}

1946年から1975年までの30年間に癌研で治療を行なつ た原発性女子尿道癌10例の治療成績を検討した。

1） 10例の平均年齢は56歳であつた。

2）組織学的には扁平上皮癌が最も多く 5 例，移行上 皮癌 2 例, 腺癌 2 例, 基底細胞癌 1 例であつた。

3） stage は $\mathrm{T} 1: 4$ 例, $\mathrm{T} 2: 2$ 例, $\mathrm{T} 3: 3$ 例, $\mathrm{T} 4:$ 1 例で, T1，T2に生存例が多い。

4）主訴は外尿道口の腫瘤 3 例，排尿痛 2 例，尿閉， 出血, 排尿困難, 肉眼的血尿, 排尿後の異和感が各 1 例 であつた。

5）原発栄の治療は放射線療法単独 6 例，手術・放射 線併用 3 例, 手術単独 1 例. 最近の 2 例飞 bleomycin を放射線療法に併用した。一次治㾤は 10 例中 9 例に得ら れた。

6）合併症として照射後尿道狭窄を 2 例に経験した が，これらに対して拡張を行なつた。

7）本報告例括よび文献的考察により次の様な治療方 針が想定される.

(i) $\mathrm{T}$ 分類別治療

$\mathrm{T} 1$ : 切除又は放射線単独療法. $\mathrm{T} 2$ : 尿道部分切除と 放射線療法の併用. T3，T4：根治的手術療法 お。び 放 射線療法の併用.

（ii）所属リンパ節に対する治療

鼡径部に対して触診上疑われるリンパ節の生検を行な い，陽性であれば根治的腸骨巣径部リンパ節廓清術を行 なう，骨盤部リンパ節に対しては転移を認めれば廓清術 を行なう。

稿を終えるにあたり御指導, 御協力いただいた当院放 射線科の諸先生に心から感謝いたします。なお本論文の 
要旨は1976年 1 月 22 日第 363 回日本泌尿器科学会東京地 方会および1976年 4 月 8 日第64回日本泌尿器科学会総会 で発表した。

\section{文献}

1) Antoniades, J.: Radiation therapy in carcinoma of the female urethra. Cancer, 24, 70—76, 1969.

2) Brack, C.B. and Dickson, R.J.: Carcinoma of the female urethra. Amer. J. Roentgenol., 79, 472-478, 1958.

3) Bracken, R.B., Johnson, D.E., Miller, L.S., Ayala, A.G., Gomez, J.J. and Rutledge, F.: Primary carcinoma of the female urethra. J. Urol., 116, 188-192, 1976.

4) Chu, A.M.: Female urethral carcinoma. Radiology, 107, 627—630, 1973.

5) Desai, S., Libertino, J.A. and Zinman, L.: Primary carcinoma of the female urethra. J. Urol., 110, 693-695, 1973.

6) Doland, E.M. : Eisenstaedt, J.S.: Amer. J. Surg., 81, 612-617, 1951 より引用.

7) Eisenstaedt, J.S.: Primary carcinoma of the female urethra with metastases. Amer. J. Surg., 81, 612-617, 1951.

8) Grabstald, H., Hilaris, B., Henschke, U. and Whitmore, W.F.: Cancer of female urethra. JAMA, 197, 835-842, 1966.

9) Grabstald, H.: Tumors of the urethra in men and women. Cancer 32, 1236-1255, 1973.

10) Graves, R.C. and Guiss, L.W.: Tumors of the urethra. J. Urol., 46, 925-947, 1961.

11) Marshall, F.C., Uson, A.C. and Melicow, M.M.: Neoplasms and caruncles of the female urethra. Surg. Gynec. Obstet., 110, 723-733, 1960.

12) Menville, J.G. and Counseller, V.S.: Mucoid carcinoma of the female urethra. J. Urol., 33, 76-81, 1935.

13) Monaco, A.P., Murphy, G.B. and Dowling, W.: Primary cancer of the female urethra. Cancer, 11, 1215-1221, 1958.

14) Peterson, D.T., Dockerty, M.B., Utz, D.C. and
Symmonds, R.E.: The peril of primary carcinoma of the urethra in women. J. Urol., 110, 72-75, 1973.

15) Pointon, R.C.S. and Poole-Wilson, D.S.: Primary carcinoma of the urethra. Brit. J. Urol., 40, 682-693, 1968.

16) Rhamy, R.K., Boldus, R.A., Allison, R.C. and Tapper, R.I.: Therapeutic modalities in adenocarcinoma of the female urethra. J. Urol., 109, 638-640, 1973.

17) Riches, E.W. and Cullen, T.H.: Carcinoma of the urethra. Brit. J. Urol., 23, 209-221, 1951.

18) Ritter, D.W.: Primary malignancy of the female urethra. Western J. Surg., 61, 420-429, 1953.

19) Rogers, R.E. and Burns, B.: Carcinoma of the female urethra. Obstetrics and Gynecology, 33, 54-57, 1969.

20) Skjaeraasen, E.: Carcinoma of the female urethra. Acta. Obst. et Gynec. Scandinav., 48, 589-597, 1969.

21) Staubitz, W.J., Carden, L.M., Oberkircher, O.J., Lent, M.H. and Murphy, W.T.: Management of urethral carcinoma in the female. J. Urol., 73, 1045-1053, 1955.

22) Taggart, C.G., Castro, J.R. and Rutledge, F.N.: Carcinoma of the female urethra. Amer. J. Roentgenol., 114, 145—151, 1972.

23) 高部吉庸, 寺島東洋三 : 放射線と抗癌剤の併用 （I），2．エールリッ七と腹水腫瘍に対するX 線とブレオマイシンの併用効果. 癌の臨床, 22, 134-137, 1976.

24）山下久雄, 長瀬徹也, 網野三郎, 阿部公彦, 鎌 田力三郎, 中条秀夫, 金田浩一, 横山 正, 五 味 誠, 小林敏雄, 御屍修一: 悪性腫瘍飞対す る放射線と Bleomycin との併用療法. 1, 571一 $581,1974$.

25) Zeigerman, J.H. and Gordon, S.F.: Cancer of the female urethra. Obstetrics and Gynecology, 36, 785-789, 1970.

（1979年10月 4 日受付） 